\title{
Catalytic Oxidation of Aqueous Sulfide Promoted by Oxygen Functionalities on the Surface of Activated Carbon Briquettes Produced from Viticulture Wastes
}

\author{
Ana C. Deiana, ${ }^{*, a}$ Marianela Gimenez, ${ }^{a}$ Maria F. Sardella, ${ }^{a}$ Karim Sapag, ${ }^{b}$ \\ Ana L. S. Masseo, ${ }^{c}$ Ana P. C. Teixeira, ${ }^{c}$ Maria H. Araujo ${ }^{c}$ and Rochel M. Lago ${ }^{c}$ \\ anstituto de Ingeniería Quimica, Universidad Nacional de San Juan, Mitre 396 (E), \\ J5402CWH San Juan, Argentina \\ ${ }^{b}$ Departamento de Física, Universidad Nacional de San Luis, \\ Ejercito de Los Andes 950, D5700HHW San Luis, Argentina \\ 'Departamento de Química, Universidade Federal de Minas Gerais, \\ 31270-901 Belo Horizonte-MG, Brazil
}

\begin{abstract}
Nesse trabalho, a oxidação catalítica do contaminante sulfeto em meio aquoso foi estudada na presença de carvão ativado na forma de briquetes mecanicamente resistentes e versáteis produzidos a partir de resíduos da indústria do vinho, i.e., semente e cachos. Caracterizações por microscopia eletrônica de varredura combinada com espectroscopia de dispersão de raios X (SEM/EDS), área superficial Brunauer-Emmett-Teller (BET), Raman, termogravimetria (TG), difração de raio X (XRD) e titulação potenciométrica indicam materiais com alta área mesoporosa e grande quantidade de grupos superficiais oxigenados. Esses briquetes mostraram alta atividade para a oxidação de sulfetos em meio aquoso, mesmo comparados com um carvão ativado comercial de elevada área superficial. A eficiência na oxidação de sulfeto é discutida em termos de dois efeitos: a elevada concentração de grupos superficiais redox do tipo quinona/hidroquinona formados a partir da decomposição do mosto da uva e a alta macro/mesoporosidade dos materiais que facilita a difusão das diferentes espécies durante a reação.
\end{abstract}

In this work, the catalytic oxidation of the hazardous and unpleasant aqueous sulfide contaminant was investigated by activated carbon in the form of mechanically resistant and versatile briquettes produced from two different wastes of the wine industry, i.e., lex and stalk. Characterization by scanning electron microscopy with energy dispersive X-ray spectroscopy (SEM/EDS), surface area Brunauer-Emmett-Teller (BET), Raman, thermogravimetry (TG), $\mathrm{X}$-ray diffractometry (XRD) and potentiometric titration showed that the materials have high mesoporous area with a large number of surface oxygen functionalities. These briquettes showed high efficiency for the oxidation of sulfides in aqueous medium, which is discussed in terms of two effects: the relatively high concentrations of quinone/hydroquinone surface redox groups formed from the grape must binder and the macro/mesoporosity, which facilitates the diffusion of the different species during the reaction.

Keywords: sulfide, catalytic oxidation, activated carbon

\section{Introduction}

Hydrogen sulfide, $\mathrm{H}_{2} \mathrm{~S}$, is a toxic and very unpleasant gas, which can cause corrosion problems in equipment and constructions. ${ }^{1,2}$ The contaminant $\mathrm{H}_{2} \mathrm{~S}$ can be removed from aqueous media using different methods such as precipitation, ${ }^{3}$ adsorption ${ }^{4}$ and electrochemical processes. ${ }^{5}$ Microorganisms

*e-mail: cdeiana@unsj.edu.ar such as Wolinellasuccinogenes, Rhodobactercapsulatus, Pelodictyonluteolum and some Chlorobium ${ }^{6}$ can also oxidize sulfide into elemental sulfur and other species, e.g., polysulfides, thiosulfate, thionates and sulfate ${ }^{7}$ in aqueous medium. It is believed that the sulfide oxidation, by microorganisms, occurs by an enzymatic process (sulfide quinone reductase enzyme). ${ }^{8,9}$

Recent works ${ }^{10,11}$ have shown that different forms of carbon, such as graphene, graphite and modified 
activated carbon, catalyze the oxidation sulfide into aqueous polysulfides and further to sulfur oxides. It has been suggested that these carbons can mimic the enzyme with their surface oxygen groups and the graphite based conductive structures. ${ }^{10,11}$ However, the high cost of these materials and the complex surface modification procedures to produce the active catalytic sites hinder their industrial application.

In this work, sulfide oxidation was investigated using special activated carbons shaped as briquettes produced from winery wastes. Briquettes are industrially much more interesting than powder and granular carbons, due to their versatility, facile manipulation and application. ${ }^{12,13}$ Several works describing the preparation and application of carbon briquettes in adsorption processes can be found in the literature..$^{14}$

Winery constitutes an important part of the economy in several regions in the world and grape is one of the most important fruit crops. ${ }^{15}$ These activities generate important volumes of wastes, like grape stalks (ca. 30\%), grape seed (ca. $30 \%$ ) and ca. $40 \%$ of skin and pulp. Stalk is the skeleton of the grape bunch and consists of lignified tissues with a high content of fibers such as lignin, cellulose, hemicellulose, with high carbon content. ${ }^{16,17}$ Grape seeds are a complex matrix containing approximately $40 \%$ fiber, $16 \%$ oil, $11 \%$ proteins and $7 \%$ complex phenols, including tannins, in addition to sugars and mineral salts. After oil extraction, the seeds form a lignocellulosic waste called lex. ${ }^{18,19}$ Both wastes, stalk and seed lex, are currently used to produce only energy by burning and the development of products with added value from these wastes is of considerable interest.

Hereon, it is demonstrated the high catalytic activity of activated carbon (AC) briquettes for sulfide oxidation in aqueous medium, which is discussed in terms of the macro/mesoporosity with high concentration of oxygen surface groups active.

\section{Experimental}

Materials

The grape stalks (ca. 12.5 wt.\% ash, 20.2 wt.\% moisture, $53.5 \mathrm{wt} . \%$ volatiles and $13.9 \mathrm{wt} . \%$ fixed carbon) and the lex (ca. 5.6 wt.\% ash, 19.3 wt.\% moisture, 44.4 wt. \% volatiles and 30.7 wt.\% fixed carbon) were obtained from Bodegas Callia and Olivi Hnos., respectively. Concentrated grape must with density of $1.35 \mathrm{~kg} \mathrm{~L}^{-1}$ and sugar (fructose and glucose) content of $860 \mathrm{~g} \mathrm{~L}^{-1}$, was used as binder to prepare the briquettes. A sample of commercial activated carbon (Aldrich) was used as reference in the reaction of sulfide.

\section{Carbonization and leaching}

Wastes, as received, were heated in an inert atmosphere at a rate of $1.4{ }^{\circ} \mathrm{C} \mathrm{min}^{-1}$, from room temperature up to $500{ }^{\circ} \mathrm{C}$ and kept at that temperature for $2 \mathrm{~h}$. This step was carried out in a stainless steel carbonization reactor electrically heated. Each carbonized material was weighted and separated in two fractions. One of them was submitted to a leaching treatment with hydrochloric acid ( $5 \% \mathrm{wt} / \mathrm{wt})$, at room temperature, in order to decrease mineral impurities, washed and dried at $25^{\circ} \mathrm{C}$.

Both fractions were ground to particle sizes bellow $0.18 \mathrm{~mm}$.

\section{Briquetting}

Carbonized materials and those carbonized and leached were briquetted using grape must as binder. The briquettes were made by mixing measured amounts of char and binder in a ratio of $4: 1$. One gram of the resulting mixture was submitted to pressures of $140 \mathrm{MPa}$ for $6 \mathrm{~min}$, into a $10 \mathrm{~mm}$ i.d. cylindrical stainless steel mold held in a hydraulic press. The obtained briquettes had $10 \mathrm{~mm}$ diameter $\times$ $13 \mathrm{~mm}$ length.

\section{Activation}

Briquettes were activated under steam flow in a stainless steel tubular reactor ( $30 \mathrm{~mm}$ i.d. and $300 \mathrm{~mm}$ length), heated in an electric furnace with automatic temperature control. The heating step, from room to activation temperatures at $15{ }^{\circ} \mathrm{C} \mathrm{min}{ }^{-1}$ was carried out in flowing nitrogen gas. In all assays, the reactor was loaded with $15 \mathrm{~g}$ of briquettes, which were submitted to a steam flow of $1.7 \mathrm{~g}(\mathrm{~g} \mathrm{~h})^{-1}$ during $105 \mathrm{~min}$. Steam was generated in a system composed by a heat exchanger and a Masterflex peristaltic pump. Once the activation step had taken place, the activated briquettes were measured, weighed, and stored.

The briquettes production can be schematized as shown in Figure 1.

The briquettes were characterized by thermogravimetry (TG)/derivative thermogravimetry (DTG) (Shimadzu,

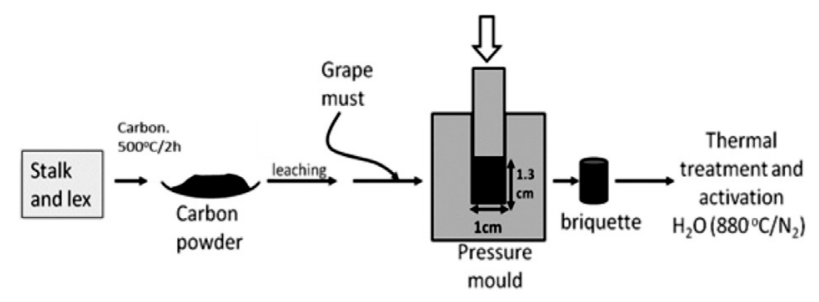

Figure 1. Schematic preparation procedure of the briquettes. 
under air with a heating rate of $10{ }^{\circ} \mathrm{C} \min ^{-1}$ up to $900{ }^{\circ} \mathrm{C}$ ), Raman spectroscopy (SENTERRA at $\lambda=514.5 \mathrm{~nm}$ ), surface area Brunauer-Emmett-Teller (BET) (Quantachrome), $\mathrm{X}$-ray diffraction (XRD) (Rigaku D/MAX Cu radiation), scanning electron microscopy with energy dispersive X-ray spectroscopy (SEM/EDS) (JEOL JSM - 6360LV microscope, operated at a voltage of $15 \mathrm{kV}$ under high vacuum). The potentiometric titrations of the materials were performed in a sealed cell with $\mathrm{N}_{2}$ purge and an automatic titrator Metrohm 670. AC (75 mg) was dispersed in $30 \mathrm{~mL}$ of a solution containing $\mathrm{HCl}\left(0.005 \mathrm{~mol} \mathrm{~L}^{-1}\right)$ and $\mathrm{NaCl}\left(0.045 \mathrm{~mol} \mathrm{~L}^{-1}\right)$, the mixture was titrated with $\mathrm{NaOH}$ $\left(0.050 \mathrm{~mol} \mathrm{~L}^{-1}\right)$. The data on $\mathrm{pH}$ and volume of titrant used was then adjusted by a nonlinear regression program developed in MATLAB 6.5, based on the work of Gorgulho. ${ }^{20}$

The oxidation reactions were investigated with $20 \mathrm{mg}$ of activated briquettes suspended in $6 \mathrm{~mL}$ of aqueous solution of $\mathrm{Na}_{2} \mathrm{~S} .9 \mathrm{H}_{2} \mathrm{O}\left(0.033 \mathrm{~mol} \mathrm{~L}^{-1}, 8.0 \mathrm{~g} \mathrm{~L}^{-1}\right)$ at $25^{\circ} \mathrm{C}$. Kinetic studies were carried out monitoring the electronic absorption UV-Vis at the wavelength $290 \mathrm{~nm}$ at different times until 60 min. A Shimadzu UV 2550 spectrometer, interfaced with a microcomputer was used. After the reaction time ( $60 \mathrm{~min}$ ), the activated briquettes were easily recovered from the reaction medium, washed twice with water and reused.

\section{Results and Discussion}

The briquette preparation was carried out by pyrolysis of the winery wastes to produce the carbon powder precursors. These carbon powders were then mixed with grape must, pressed in a mold, thermally treated and activated with steam (Figure 1).

Four different briquette samples were obtained and named hereon as $\mathrm{S}_{\mathrm{HCl}}$ (stalk precursor with $\mathrm{HCl}$ leaching), $\mathrm{L}$ (lex precursor) and $\mathrm{L}_{\mathrm{HCl}}$ (lex with $\mathrm{HCl}$ leaching) all activated at $880{ }^{\circ} \mathrm{C}$. The $\mathrm{HCl}$ leaching was carried out in order to remove any soluble metal that could interfere in the sulfide reaction.

The briquette prepared from stalk without leaching reached a burn off around $100 \%$ when activated at $880{ }^{\circ} \mathrm{C}$. Therefore activation at $700{ }^{\circ} \mathrm{C}$ was performed to obtain briquettes with acceptable mechanical and textural properties $\left(\mathrm{S}_{700}\right)$.

SEM analyses (Figure 2) of the lex (L) sample clearly showed compact carbon particles with dimensions near 20-200 $\mu \mathrm{m}$ agglomerated to form the briquette structure. It is interesting to observe that the interstitial spaces between these carbon particles are filled with microstructured less organized carbon. This interstitial carbon is likely formed by the decomposition of the binder grape must. It can also
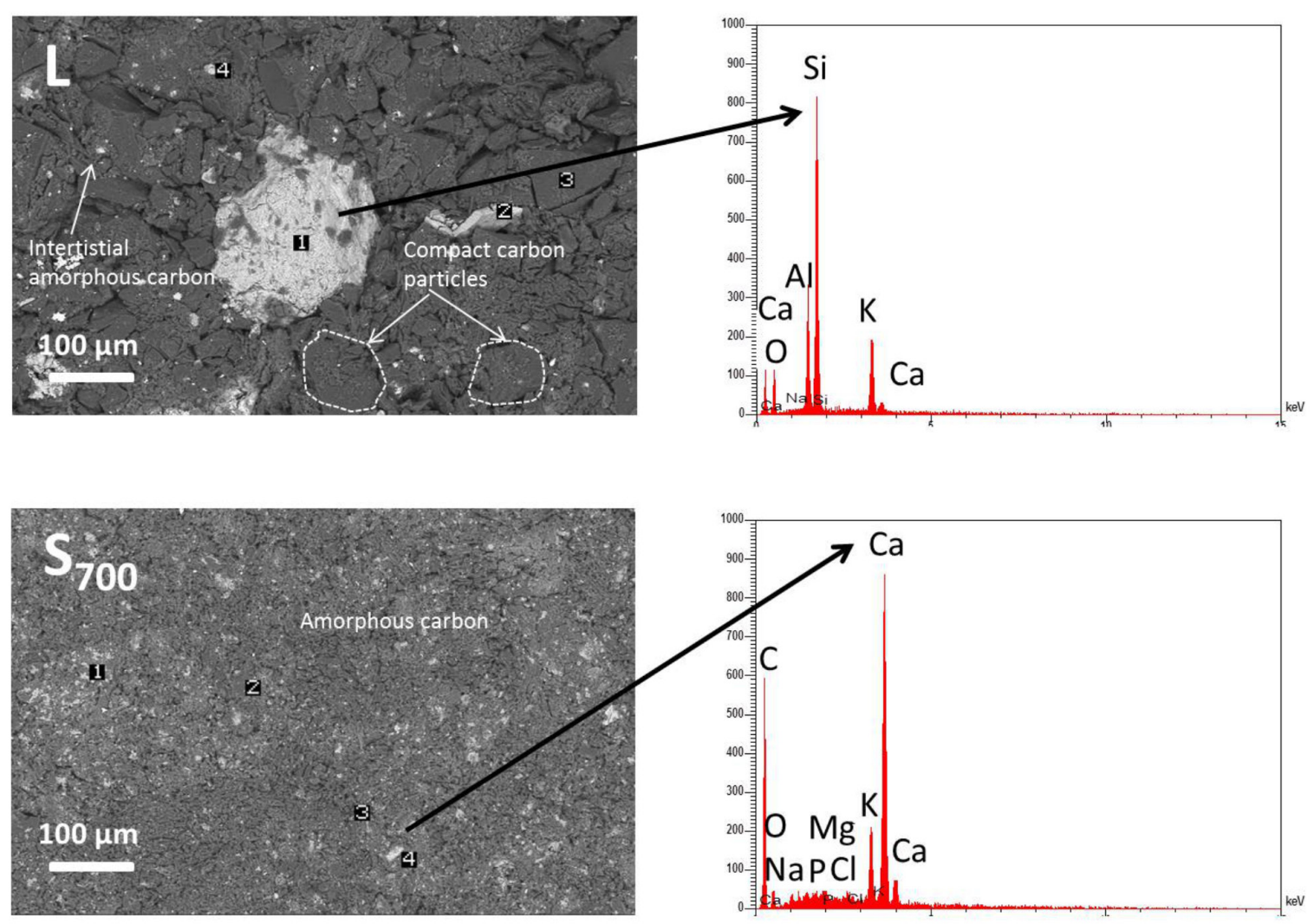

Figure 2. SEM images and EDS obtained for the sample $\mathrm{L}$ and $\mathrm{S}_{700 \text {. }}$ 
Table 1. Surface area and porosity for the briquette samples

\begin{tabular}{lcccc}
\hline Sample & $\mathrm{S}_{\mathrm{BET}} /\left(\mathrm{m}^{2} \mathrm{~g}^{-1}\right)$ & $\mathrm{V}_{\mu \mathrm{p}-\mathrm{t}} /\left(\mathrm{cm}^{3} \mathrm{~g}^{-1}\right)^{\mathrm{a}}$ & $\mathrm{V}_{\mathrm{mp}} /\left(\mathrm{cm}^{3} \mathrm{~g}^{-1}\right)$ & $\mathrm{V}_{\mathrm{Tp}} /\left(\mathrm{cm}^{3} \mathrm{~g}^{-1}\right)^{\mathrm{b}}$ \\
\hline $\mathrm{S}_{700}$ & 285 & 0.10 & 0.03 & 0.13 \\
$\mathrm{~S}_{\mathrm{HCl}}$ & 723 & 0.25 & 0.12 & 0.37 \\
$\mathrm{~L}$ & 795 & 0.27 & 0.12 & 0.39 \\
$\mathrm{~L}_{\mathrm{HCl}}$ & 669 & 0.22 & 0.13 & 0.35 \\
$\mathrm{AC}$ & 890 & 0.37 & 0.06 & 0.43 \\
\hline
\end{tabular}

${ }^{\mathrm{a}} \mathrm{V}_{\mu \mathrm{p}-\mathrm{t}}(\mathrm{t}-\mathrm{plot})$ and ${ }^{\mathrm{b}} \mathrm{V}_{\mathrm{Tp}}($ Gurvich$)$.

be observed the presence of $\mathrm{Si}$ rich white particles ranging from few micrometers up to $200 \mu \mathrm{m}$ likely related to silica sand contamination. SEM analyses of the stalk briquette $\left(\mathrm{S}_{700}\right)$ showed a much less organized carbon structure, probably due to the structure of the stalk carbon precursor and to the grape must binder decomposition. The $\mathrm{S}_{700}$ sample also showed the presence of inorganic white particles in general smaller than $10 \mu \mathrm{m}$. EDS analyses of these white particles suggest the presence of significant amounts of $\mathrm{K}$ and $\mathrm{Ca}$. After $\mathrm{HCl}$ leaching, no significant difference was observed in the texture and EDS composition for both carbons [see the Supplementary Information (SI) section].

The obtained surface areas and porosities for the different samples are shown in Table 1 (adsorption isotherms are shown in SI).

The $S_{700}$ sample showed a relatively low surface area of $285 \mathrm{~m}^{2} \mathrm{~g}^{-1}$ due to the low activation temperature, i.e., $700{ }^{\circ} \mathrm{C}$. On the other hand, upon leaching and activation at $880^{\circ} \mathrm{C}$, the $\mathrm{S}_{\mathrm{HCl}}$ sample showed an increase of the surface area to $723 \mathrm{~m}^{2} \mathrm{~g}^{-1}$ with micropores $\left(0.25 \mathrm{~cm}^{3} \mathrm{~g}^{-1}\right)$ and an important contribution of mesopores $\left(0.12 \mathrm{~cm}^{3} \mathrm{~g}^{-1}\right)$. The briquette obtained from the lex precursor showed surface areas between $669-795 \mathrm{~m}^{2} \mathrm{~g}^{-1}$. The AC used as reference is mainly microporous with a higher surface area of $890 \mathrm{~m}^{2} \mathrm{~g}^{-1}$.

Raman analyses were used to characterize the nature of the carbon present in the briquettes (Figure 3). The obtained spectra showed the presence of the band near $1580 \mathrm{~cm}^{-1}$ ( $G$ band) typical of more organized graphitic materials and a band at $1320 \mathrm{~cm}^{-1}$ (D band), which suggests the presence of more defective amorphous carbon structures. ${ }^{21}$ The relative intensity of $\mathrm{G}$ and $\mathrm{D}$ bands can be related to the organization degree of the carbon material. ${ }^{22}$ The $\mathrm{I}_{\mathrm{G}} / \mathrm{I}_{\mathrm{D}}$ ratio observed for lex samples (both $\mathrm{L}$ and $\mathrm{L}_{\mathrm{HCl}}$ ) $\left(I_{G} / I_{D}\right.$ ca. 1.0) is slightly larger than the observed for $\mathrm{S}_{\mathrm{HCl}}$ sample $\left(\mathrm{I}_{\mathrm{G}} / \mathrm{I}_{\mathrm{D}}=0.8\right)$, suggesting that the carbon present in the lex sample is more organized compared to the carbon formed in the stalk after activation at $880{ }^{\circ} \mathrm{C}$.

$\mathrm{XRD}$ analyses for the two carbon briquettes agree with Raman, indicating the presence of graphitic crystallites by the presence of a large peak near $27^{\circ}$ (SI section).

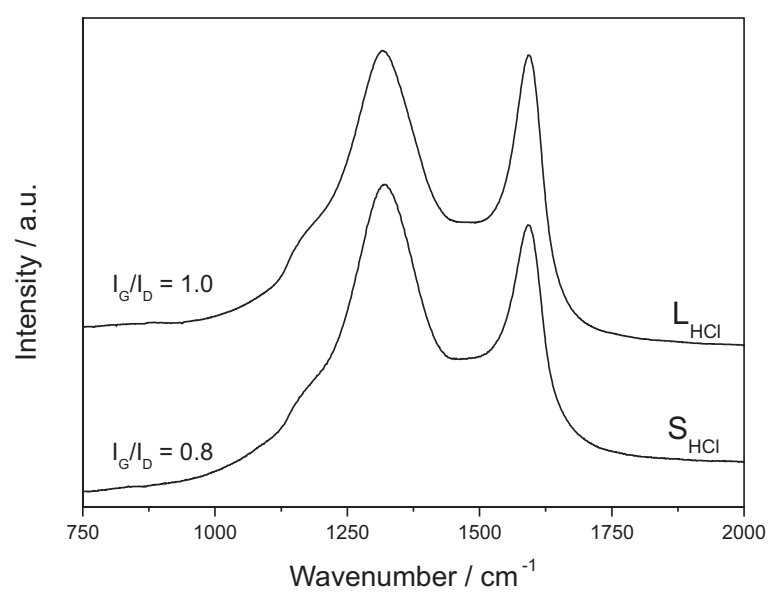

Figure 3. Raman spectra of $\mathrm{L}_{\mathrm{HCl}}$ and $\mathrm{S}_{\mathrm{HCl}}$ samples.

TG/DTG analysis (Figure 4) in air atmosphere of the L briquette sample, after the leaching process, $\left(\mathrm{L}_{\mathrm{HCI}}\right)$ and of the sample before the leaching, L (SI section) showed similar weight losses of ca. $90 \%$ near $500^{\circ} \mathrm{C}$. These weight losses are related to carbon oxidation. The ashes (approximately 10\%) are related to inorganic impurities, such as metal oxides and silica, originally present in the lex and steam wastes. This result suggests that the leaching process does not have any significant effect on the inorganic contaminants present in the sample. It is interesting to observe that the sample $\mathrm{S}_{\mathrm{HCl}}$ showed oxidation temperatures near $400{ }^{\circ} \mathrm{C}$, significantly lower than the L carbon $\left(\mathrm{ca} .500^{\circ} \mathrm{C}\right.$ ), suggesting the presence of a more defective and reactive carbon. This result agrees with the Raman analyses, which indicated that the lex sample is formed by a more organized graphitic carbon.

The nature and concentration of the oxygen surface groups present in the carbon samples were determined by potentiometric titration. Figure 5 shows the concentration of oxygen surface groups according to their $\mathrm{pKa}$, for the different samples studied. The presence of sites with $\mathrm{pKa}<5$ suggests the formation of carboxylic groups. Lactones and carboxylic anhydride groups may also be present, and could be ascribed to pKa ranging between 5 and 7. Sites with pKa $>9$ are indicative of the presence of phenols and quinones groups. ${ }^{20}$ 


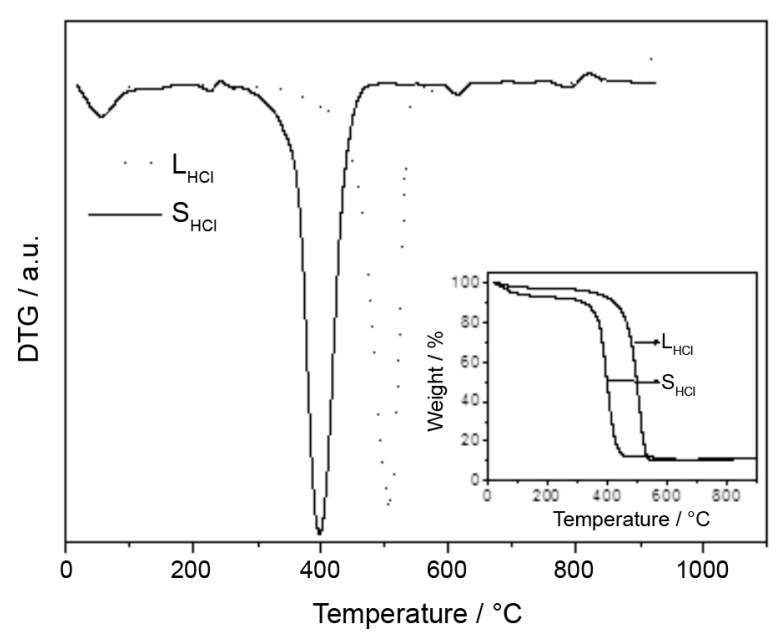

Figure 4. TG/DTG analyses for $\mathrm{L}_{\mathrm{HCl}}$ and $\mathrm{S}_{\mathrm{HCl}}$ in air atmosphere.

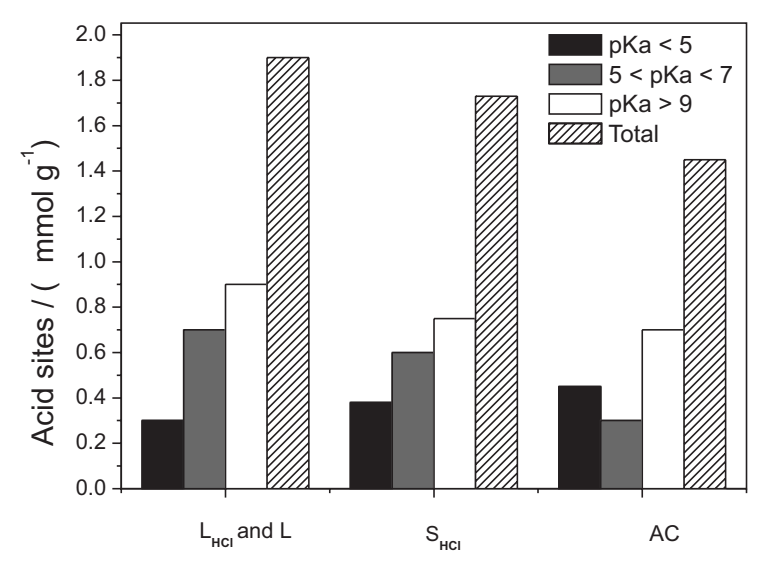

Figure 5. Number of oxygen sites in $\mathrm{L}, \mathrm{L}_{\mathrm{HCl}}, \mathrm{S}_{\mathrm{HCl}}$ and $\mathrm{AC}$.

The obtained results for the $\mathrm{L}$ and $\mathrm{L}_{\mathrm{HCl}}$ samples showed similar number of oxygen surface groups of ca. 1.96 and $1.86 \mathrm{mmol} \mathrm{g}^{-1}$, respectively. The point of zero charge (PZC) determination for these samples showed values of 11.4 and 12.1. On the other hand, the $\mathrm{S}_{\mathrm{HCl}}$ sample showed a slightly lower total oxygen surface groups of ca. $1.70 \mathrm{mmol} \mathrm{g}^{-1}$ with a PZC of 10. It is interesting to observe that the carbons, L, $\mathrm{L}_{\mathrm{HCl}}$ and $\mathrm{S}_{\mathrm{HCl}}$ showed relatively high concentration of surface groups with pKa higher than 9 , suggesting the presence of phenolic and quinone like groups. The commercial AC, used as reference, showed much lower total oxygen surface groups of ca. $0.14 \mathrm{mmol} \mathrm{g}^{-1}$.

\section{Sulfide oxidation}

Previous works ${ }^{10,11}$ showed that different forms of carbon, such as graphite and graphene and modified carbons promote the oxidation of aqueous sulfide initially to polysulfides, e.g., $\mathrm{S}_{2}{ }^{2-}, \mathrm{S}_{3}{ }^{2-}$ and $\mathrm{S}_{4}{ }^{2-}$. These sulfide intermediates form a yellow solution and they can be identified by absorptions in the UV-Vis spectrum at 267 ,
290 and $375 \mathrm{~nm}$, respectively. These polysulfides are further oxidized to form complex mixtures of oxygenated sulfur species, which can be easily identified by infrared (IR). ${ }^{11}$

The carbon briquettes obtained in this work were used as catalyst for sulfide oxidation. An evolution of the UV-Vis spectra during the reaction with aqueous sulfide and $\mathrm{L}_{\mathrm{HCl}}$ carbon is shown in Figure 6.

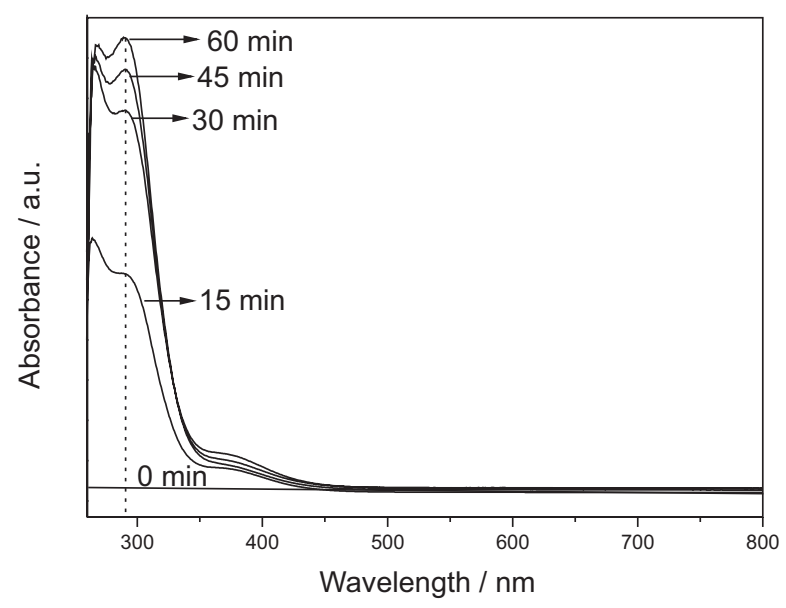

Figure 6. UV-Vis spectral evolution during the disodium sulfide oxidation at $25^{\circ} \mathrm{C}$ using $\mathrm{L}_{\mathrm{HCl}}$.

After 15 min of reaction, three new bands (267, 290 and $375 \mathrm{~nm}$ ) can be observed, characteristic of the formation of polysulfides. The UV-Vis spectra for the reaction in the presence of other carbons are shown in the SI section. Kinetic measurements using the absorption at $290 \mathrm{~nm}$ for the reaction in the presence of the different briquette carbons are exhibited in Figure 7.

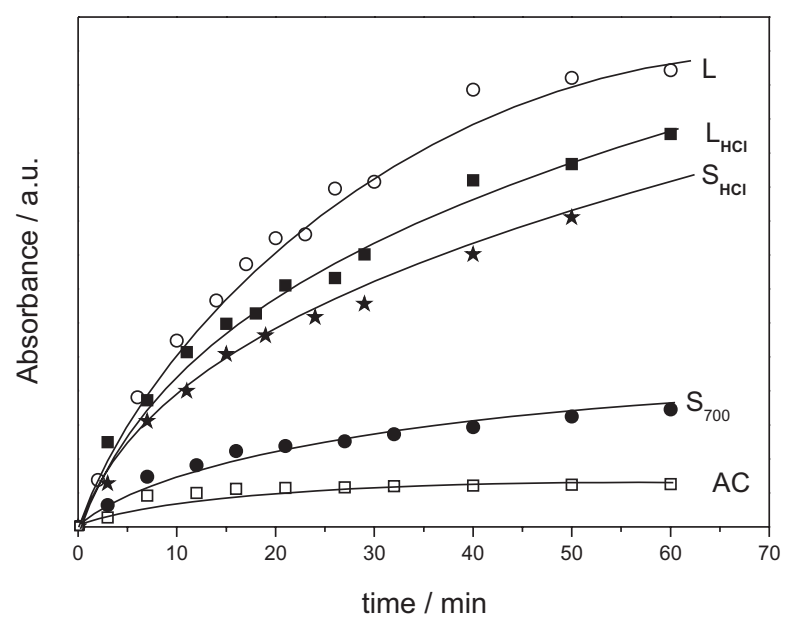

Figure 7. Polysulfide formation (band at $290 \mathrm{~nm}$ ) during the reaction of aqueous $\mathrm{Na}_{2} \mathrm{~S}$ with the briquette samples and commercial AC.

It can be observed that the sample $\mathrm{L}$ showed the highest activity for the oxidation of sulfide followed by $\mathrm{L}_{\mathrm{HCl}}$ and $\mathrm{S}_{\mathrm{HCl}}$. On the other hand, commercial AC showed very low activity. 
The higher reactivity of the sample $\mathrm{L}$ is partly related to the higher surface area $\left(795 \mathrm{~m}^{2} \mathrm{~g}^{-1}\right)$ compared to $\mathrm{L}_{\mathrm{HCl}}$ and $\mathrm{S}_{\mathrm{HCl}}\left(669\right.$ and $723 \mathrm{~m}^{2} \mathrm{~g}^{-1}$, respectively). Much lower activities were observed for the samples $S_{700}$, which is likely related to the much lower surface area $\left(285 \mathrm{~m}^{2} \mathrm{~g}^{-1}\right)$. Also, larger pores, i.e., meso and macropores, seem to play an important role during the reaction, according to some of our recent work. ${ }^{10,11}$ Although the nature of the effect of pore size on the reaction is not clear, it is likely related to the diffusion limitation of sulfur species into/out the micropores. The briquette carbons obtained in this work showed important meso (see Table 1) and macroporosity (see SEM images) formed in the spaces between the carbon base grains. Figure 8 shows schematically how these pores are formed during the production of the briquettes.

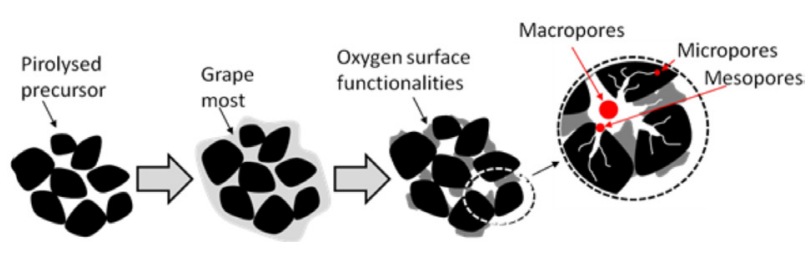

Figure 8. Formation of macro, meso and microporosity during grape must decomposition in the briquette formation.

Although the reaction mechanism is not clear, previous works ${ }^{10,11}$ suggest that surface oxygen group combined with the electric conductivity of the carbon are fundamental for the reaction. During the briquette formation, grape must, rich in different sugars, is used as binder and decomposes on the surface of the base carbon particles previously formed. The decomposition of these sugars should produce a carbon with relatively high oxygen content. Potentiometric titrations showed that the oxygen surface groups are much higher compared to a commercial activated carbon and that most of these groups have pKa higher than 9, suggesting the presence of quinone and hydroquinone functionalities. It can be inferred that this surface carbon formed by grape must decomposition plays an important role during the reaction as suggested in Figure 9. ${ }^{19}$

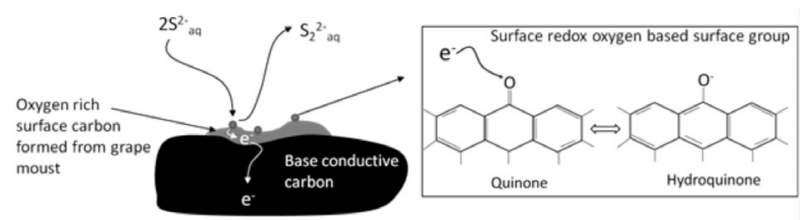

Figure 9. Proposed view of the briquette carbon composed of a based carbon and surface rich in oxygen and a possible redox mechanism.

In fact, it has been suggested ${ }^{10,11}$ that carbons can behave like the quinone-reductase enzymes, where the combination of quinone redox group with an efficient electron transport system is considered the key-features for an efficient catalyst. A similar mechanism can be proposed for the reaction in the presence of the activated carbon briquettes (Figure 9). The sulfide can be oxidized by surface quinone groups and one electron is transferred to the carbon. Initially, this electron is located at the oxygen in the form of a hydroquinone group. This electron is then transferred to another region of the bulk carbon by conductive areas formed by graphitic material. Raman and TG analyses suggested that especially the L carbons are composed of a more organized and therefore more conductive type of carbon.

It is interesting to observe that although microporous commercial AC has the highest surface are $\left(890 \mathrm{~m}^{2} \mathrm{~g}^{-1}\right)$ and similar concentration and type of oxygen surface groups, it showed the lowest sulfide oxidation activity compared to all the other briquette samples. This is likely related to two main factors: the presence of micropores (diameter $<20 \AA$ ) that limit the diffusion of the reactant and products $\left(\mathrm{S}_{2}{ }^{2-}\right.$, $\mathrm{S}_{3}{ }^{2-}$ and $\mathrm{S}_{4}{ }^{2-}$ ) with molecular sizes ranging from $2-6 \AA^{23}$ and some aspects of the electrical conductivity in the carbon structure.

In order to investigate the deactivation of the carbon catalyst, the briquette sample $\mathrm{L}$ was reused three times by simple separation and addition of a fresh $\mathrm{Na}_{2} \mathrm{~S}$ solution. The results are shown in Figure 10. It can be observed a constant deactivation after each use. A similar deactivation was observed for the sample $\mathrm{L}$ after a thermal treatment at $900{ }^{\circ} \mathrm{C}$ under vacuum for $1 \mathrm{~h}$. This deactivation is likely related to the removal of surface oxygen groups by the thermal treatment.

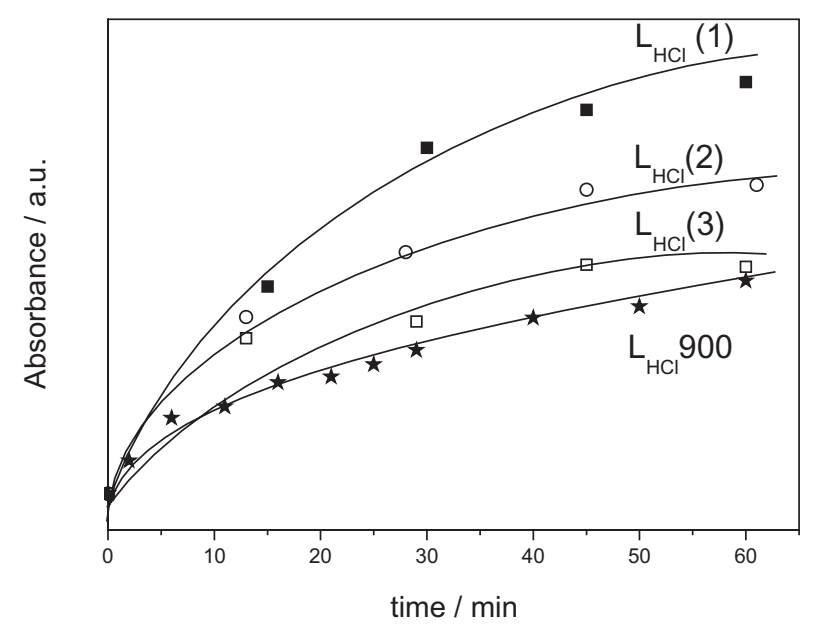

Figure 10. Consecutive reuse of the $\mathrm{L}_{\mathrm{HCl}}$ sample and $\mathrm{L}_{\mathrm{HCl}}$ treated at $900^{\circ} \mathrm{C}$ under vacuum for the sulfide oxidation in aqueous solution.

\section{Conclusions}

Activated carbon briquettes obtained from wastes of wine industry showed a relatively high catalytic activity 
for aqueous sulfide oxidation even compared with a high surface area commercial powder activated carbon. This oxidation efficiency can be discussed in terms of redox oxygen surface and surface area/porosity. The reaction is favored by the presence of quinone/hydroquinone groups, likely formed from the grape must binder decomposition on the briquette surface combined with an electron conductive structure, formed by more organized graphitic carbon. Moreover, the briquettes show a macro/mesoporosity, which facilitates the diffusion of the different species during the reaction.

\section{Supplementary Information}

Supplementary data are available free of charge at http://jbcs.sbq.org.br as PDF file.

\section{Acknowledgements}

CAPES, CAPG, Petrobras, FAPEMIG, CNPq and UNSJ.

\section{References}

1. Tchobanoglous, G.; Burton, F. L.; Stensel, H. D.; Wastewater Engineering: Treatment and Reuse, $4^{\text {th }}$ ed.; McGraw-Hill: New York, 2003.

2. Zhang, L.; De Schryver, P.; De Gusseme, B.; De Muynck, W.; Boon, N.; Verstraete, W.; Water Res. 2008, 42, 1.

3. Altas, L.; Buyukgungor, H.; J. Hazard. Mater. 2008, 153, 462.

4. Sakanishi, K.; Wu, Z. H.; Matsumura, A.; Saito, I.; Hanaoka, T.; Minowa, T.; Tada, M.; Iwasaki, T.; Catal. Today 2005, 104, 9.

5. Dutta, P. K.; Rabaey, K.; Yuan, Z.; Rozendal, R. A.; Keller, J.; Water Res. 2010, 44, 2563.

6. Henshaw, P. F.; Zhu, W.; Water Res. 2001, 35, 3605.

7. Harrison, A. P.; Annu. Rev. Microbiol. 1984, 38, 265.

8. Friedrich, C. G.; Rother, D.; Bardischewsky, F.; Quentmeier, A.; Fischer, J.; Appl. Environ. Microbiol. 2001, 67, 2873.
9. Perlinger, J. A.; Kalluri, V. M.; Venkatapathy, R.; Angst, W.; Environ. Sci. Technol. 2002, 36, 2663.

10. Lemos, B. R. S.; Teixeira, I. F.; de Mesquita, J. P.; Ribeiro, R. R.; Donnici, C. L.; Lago, R. M.; Carbon 2012, 50, 1386.

11. Lemos, B. R. S.; Teixeira, I. F.; Machado, B. F.; Alves, M. R. A.; de Mesquita, J. P.; Ribeiro, R. R.; Bacsa, R. R.; Serp, P.; Lago, R. M.; J. Mater. Chem. A 2013, 1, 9491.

12. Boyano, A.; Galvez, M. E.; Lazaro, M. J.; Moliner, R.; Carbon 2006, 44, 2399.

13. Costa, L. C. M.; Araujo, M. H.; Sapag, K.; Sardella, M. F.; Silva, H.; Deiana, A. C.; Lago, R. M.; J. Braz. Chem. Soc. 2005, $16,899$.

14. Deiana, A. C.; Granados, D. L.; Petkovic, L. M.; Sardella, M. F.; Silva, H. S.; Braz. J. Chem. Eng. 2004, 21, 585.

15. Ping, L.; Brosse, N.; Sannigrahi, P.; Ragauskas, A.; Ind. Crops Prod. 2011, 33, 200.

16. Deiana, A. C.; Sardella, M. F.; Silva, H.; Amaya, A.; Tancredi, N.; J. Hazard. Mater. 2009, 172, 13.

17. Eguees, I.; Serrano, L.; Amendola, D.; De Faveri, D. M.; Spigno, G.; Labidi, J.; Renew. Energ. 2013, 60, 553.

18. http://researchrepository.murdoch.edu.au/11087/1/value_ added_products.pdf accessed on October 2014.

19. Deiana, A. C.; Gimenez, M. G.; Romoli, S.; Sardella, M. F.; Sapag, K.; Adsorpt. Sci. Technol. 2014, 32, 181.

20. Gorgulho, H. F.; Mesquita, J. P.; Goncalves, F.; Pereira, M. F. R.; Figueiredo, J. L.; Carbon 2008, 46, 1544.

21. Dresselhaus, M. S.; Dresselhaus, G.; Saito, R.; Jorio, A.; Phys. Rep. 2005, 409, 47.

22. Malard, L. M.; Pimenta, M. A.; Dresselhaus, G.; Dresselhaus, M. S.; Phys. Rep. 2009, 473, 51.

23. El Jaroudi, O.; Picquenard, E.; Demortier, A.; Lelieur, J. P.; Corset, J.; Inorg. Chem. 1999, 38, 2394.

Submitted on: September 2, 2014

Published online: November 11, 2014 